\title{
ФАЗИЧНИ ПРИДЕВИ СА ЗНАЧЕЮЕМ УНУТРАШЊИХ ЉУДСКИХ ОСОБИНА
}

\begin{abstract}
У раду се на одабраним примерима придева којима се исказују унутрашње људске особине испитује могућност стварања фазичних вредности у оквиру семантичке поткатегорије којој припадају. Под унутрашњим особинама подразумевамо карактерно, интелектуално, психичко, емотивно својство човека, које представљају поткатегорије у оквиру тематског поља 'унутрашње особине'. У првом реду се испитује утицај концептуалне вредности мотивног придева на развој градуелности, а творбеном анализом се указује на утицај појединих суфикса и префикса у стварању облика с фазичном вредношћу.

Кључне речи: придеви са значењем унутрашњих људских особина, фазичне вредности, деривација, српски језик
\end{abstract}

\section{1. Основни постулати фази лингвистике}

Фази логика представља својеврстан логички систем у чијем је тежишту обележје истинитости. За разлику од „логике аристотеловског типа у којој се појаве и наши судови о њима подвргавају разврставањима по обрасцима оцењивања с обзиром на вредности тачности / нетачности, истинитости / лажности, фази логика омогућује размишљање о рангирању, степеновању исказа" (Радовановић 2008: 14-15). Степени истинитости и вероватноће изражавају се у распону од 0 до 1 (1 стоји за апсолутну истину, 0 за апсолутну лаж) у којем је могућа реализација фазичних вредности, с вишим или нижим степеном истинитости. У изражавању ових вредности користе се нумеричке, али и језичке варијабле, које се често комбинују у циљу што прецизнијег

*gordanastasni@ff.uns.ac.rs

** Рад је настао у оквиру пројекта Стандардни српски језик: синтаксичка, семантичка и прагматичка истраживања (178004), који финансира Министарство просвете, науке и технолошког развоја Републике Србије. 
изражавања степена истинитости у оквиру одређених категорија. Очигледна је веза између принципа фази логике и језичког феномена градуелности, који се може описати и као вид концептуализације и номинације различитих фазичних вредности. ${ }^{1}$ Оне се могу сагледати у различитим језичким манифестацијама, а нарочито на плану суптилног семантичког нијансирања, што се посебно јавља код јединица у чијем је концепту садржана квантитативна и квалитативна компонента (Штасни 2009: 144). ${ }^{2}$

\section{2. Семантичке специфичности придева са значењем 'унутрашње људске особине'}

Семантички опсег концепта унутрашњих људских особина веома је хетероген. С обзиром на сложен духовни свет човека, унутрашње особине које из њега произилазе обухватају све аспекте његовог унутрашњег, психичког живота - интелектуални, емотивни и морални. Стога би се укупан психички свет човека уопштено могао означити као његов карактер. Међутим, овде се јавља проблем у вези с идентификацијом придева који се могу сматрати њиховим прототипичним представницима (нпр. паметан, добар, поштен).

Према схватању М. Радовановића (2015: 79), „најбоље одређење семантике придева јесте да је она управо изразито фазична, а да је значење придева умногоме дефинисано њиховом актуелизацијом, тј. употребом у конкретном контексту, из чега проистичу проблеми с разврставањем придева у њихове семантичке (пот)класе.”’ Могућности испитивања придева као језичког средства за именовање људских особина са становишта фази логике произилазе из саме концептуалне вредности појма особина. Свака особина је у својој природи амбивалента, са својим лицем и наличјем. Заузимањем места на крајњим тачкама у донекле модификованој фази скали $(-1-\mathbf{0}-+1)$, истовремено се ствара могућност да се између позитивног и негативног пола формирају и вербализују унутрашње вредности градуелног карактера, које заједно са крајњим тачкама чине континуум, потпуно обухватајући појмовни домен одређене особине. ${ }^{4}$ Стога је у једном таквом низу могуће утврдити граничну вредност у смислу оне вредности којом се завршава једна појава и од које почиње друга, у којој се додирују два ентитета, две посебности, иако се

${ }^{1}$ О градуелности в. Радовановић 2007: 747-757

${ }^{2}$ Овај се феномен огледа и у чињеници да је ,jезик систем организмичког типа, чији се делови налазе у односу веће или мање међусобне условљености и функционалне подршке, без способности за самостално функционисање, по правилу без оштрих граница између делова тог система, са мноштвом прелазних облика" (Пипер 2002: 134).

3 „Да ли, на пример, придев злобан одредидити као придев 'са значењем особине' или 'са значењем осећања' будући да то зависи управо од контекста: Пазите, ја нисам неки злобан човек / Ипак се питам зашто ми то раде, зашто су људи злобни према мени (Радовановић 2015: 79).

${ }^{4}$ „Степенованост укључује постојање могућности поређења; када поредимо два или више ентитета у погледу посједовања одређеног својства, дато својство може бити присутно у мањој или већој мјери" (Костић 2008: 100), с тим да је могућност поређења највише својствена придевима. 
појмовима на супротним половима обухвата одређена особина у тоталитету. ${ }^{5}$ Гранична вредност (0), посматрана из једног другог угла, може се сматрати осом симетрије, дакле, као критеријум за одмеравање симетрично супротстављених чланова, са негативним (-1) и позитивним вредностима $(+1)$, нпр. (-1) лош - (0) добар - (+1) предобар (Штасни 2009: 143). Према наводима М. Радовановића (2015: 56), на основу Крофтове и Крузове расправе о скаларности у Когнитивној лингвистищи антонимски пар добар - лош припада преклапајућем бискалном систему; у питању су две симетричне, неједнаке скале које се делом преклапају.

Антонимија се у том смислу може сматрати типичном везом која се успоставља међу јединицама лексичко-семантичке скупине придева са значењем унутрашњих људских особина. Основна опозициона веза, из које произилазе све друге, заснована је на релацији придевских концепата нпр. добар и зао, рђав, лош. „Разлог њиховој значењској блискости налази се у семантичком садржају лексема у одређеном парадигматском односу. Лексеме у односу синонимије, као и у односу антонимије, садрже заједничку архисему, имају заједничко доминантно, категоријално, семантичко обележје, без обзира на то што придевски антоними, за разлику од именичких, немају лексикализовану архисему” (Штасни 2011: 241). Према Д. Шипки, антонимија је вид десигнативних садржинских релација, која се остварује када „на нивоу садржаја постоји заједнички именитељ” (1998: 44). Другачије речено, „антонимска супротстављеност семантичких садржаја налази се у једној заједничкој семи одређене особине; даље да кажемо, супротстављеност се заснива на могућности општих и симетричних односа знатна заступљеност / незнатна заступљеност или присуство / одсуство особине" (Гортан-Премк 2004: 146). ${ }^{6}$

\section{3. Номинација придевских фазичних вредности у домену менталних својстава човека}

Придеви за именовање негативних менталних својстава као унутрашњих особина човека индукују деривате којима се изражава различит степен особине садржане у појмовној вредности мотивне речи. Особина може бити изразито наглашена, или ублажена. С неутралном или почетном вредношћу на нултој тачки налази се мотивни придев, са његове леве стране на фазичној скали налазе се деривати са умањеним, а са десне стране - деривати којима се изражава пренаглашена особина именована мотивном речју. Прототипични придев којим се именује ограничена умна способност човека може бити придев глуп у значењу 'који је умно ограничен, заостао, туп; супр. паметан'. Он је део синонимног низа, са готово истозначним лексемама myn, mуnав,

\footnotetext{
${ }^{5}$ Више о овоме в. Пипер 2008: 307-322.

${ }^{6}$ Антонимност се првенствено остварује као симетрична релација, наводи Д. Шипка, мада постоје случајеви где се јавља несиметричност (1998: 47).
} 
блесав. Према Скоковом тумачењу, глуn је свесловенски и прасловенски придев без паралела у балтичком, уз напомену да је „stupidus danas više u govoru školovanih ljudi negoli u narodu koji govori budala, bena, a školovani ljudi i idiot" (1971: 574).

У РМС су лексеме глуп и глупав одређене као истозначнице премда имају различиту творбену структуру. Р. Драгићевић (2001: 37) наводи да је „могуће да се суфикси додају простим придевима по аналогији с већином придева који означавају људске особине, а који се граде помоћу суфикса.” О суфиксу -ав Клајн каже да је од придевске основе данас практично само глупав, са истим значењем као основни придев” (2003: 254). Д. Шипка објашњава да се суфиксом - ав у комбинацији с основом придева граде придевски деривати са значењем 'који испољава умерену особину садржану у мотивној речи' (ирвенав < ирвен) (2003: 38). Р. Драгићевић истиче да бисмо могли „говорити о подвојености ових варијанти и по територијалном принципу. У Кикинди ce, на пример, најчешће користи придев глупав, док се у Београду најчешће користи придев глуn (2001: 37). Суфикс -ав ипак уноси у дериват додатна обележја семантичког и прагматичког типа. Тако дериват глупав у односу на придев глуn изражава донекле ублажено својство исказано мотивним придевом, са пејоративном примесом и више је колоквијалног карактера.

Дериват глупкав 'приглуп, помало глуп' изведен је сложеним суфиксом -кав „са значењем приближности за које нема сигурних потврда” (Клајн 2003: 255). Д. Шипка (2003: 108) наводи да деривати с овим суфиксом имају значење 'који испољава умерену особину садржану у мотивној речи' (дебелкав < дебео). Умањено својство ове особине реализовано је префиксалом приглуn 'помало глуп', а најинтензивније - префиксалом преглуn 'сувише, необично глуп'. ${ }^{7}$ Префикс пре- у творби придева изражава највиши степен својства или мере.

Деривати којима се именује умањено својство исказано мотивним придевом настали су извођењем суфиксима - ав и -кав, као и префиксалом приглуn. ${ }^{8}$ Градуелне вредности придева глуn имају следећи распоред на фази скали: глупкав - приглуп - глупав - глуп - преглуп.

Придев паметан у свом основном значењу 'који има способност расуђивања, који је здрава, нормална ума, разборит, мудар' представља семантички опонент придева глуn. Његове фазичне вредности се развијају у два правца. С потпуним одсуством особине садржане у мотивној речи у придеву беспаметан 'који је без памети', с мало ублаженом негацијом у префиксалу непаметан 'који нема памети, који је слабе памети, глуп'. Са појачаним степеном изражености особине садржане у мотивном глаголу овом фазичном низу припада префиксирани придев препаметан 'одвећ, сувише паметан'. На фази скали у којој граничну вредност представља придев паметан налазе се следеће јединице: беспаметан-непаметан-паметан - препаметан.

\footnotetext{
${ }^{7}$ У РМС је придев приглуn са значењем 'прилично, подоста глуп', што не одговара семантици коју у дериват уноси префикс $п р и$-.

${ }^{8}$ Клајн (2002: 220) констатује да префикс $п р и$ - значи непотпуност, ограниченост, ублажавање особине исказане основним придевом - приглуп и припрост.
} 


\section{4. Номинација придева са фазичним вредностима у домену човекове нарави и морала}

4.1. Придев добар 'који је позитивних, племенитих особина, ваљан, врстан, одабран; супр. зао, рђав, лош' може се сматрати прототипичним придевом у категорији придева који садрже концептуалну вредност 'људска нарав' с позитивним обележјем. ${ }^{9}$ Наиме, психичке особине човека увек се процењују у односу на друге, као што је 'бити X' (добар, поштен, праведан, безазлен) и неодвојиве су од моралних особина (Штасни 2013: 47). М. Ивић (2005: 14), разматрајући когнитивне аспекте појма 'добар', истиче да у некој културној средини опредељивање ,за позитивну или негативну оцену најнепосредније зависи од њених наслеђеном културом устројених евалуативних критерија."

Са становишта лексичке семантике овај се придев наводи као пример за деплецију, али се то не одражава на његову способност за грађење деривата са фазичним вредностима. ${ }^{10}$ Углавном су то придеви субјективне оцене којима је у основи целокупан појмовни садржај мотивног придева, с придруженим компонентама сличне вредности: добричав 'који је добре и мирне ћуди', добростив 'добар, благ, милостив, милосрдан; који изражава, очитује, испољава доброту'. ${ }^{11}$ Овом градуелном низу може се прикључити и префиксирани придев подобар, и то на основу његове примарне семантичке реализације 'доста, прилично добар; прилично јак, снажан'. На фази скали се с најинтензивнијим својством садржаним у мотивном придеву налази префиксал предобар 'одвећ, сувише добар'.

Значајну улогу у деривацији придева с позитивном субјективном оценом имају префикси -ичав и -остив. Клајн наводи да је суфикс -ичав потврђен само у примерима м (j)естичав и са значењем нијансе у модричав и бледичав (2003: 255). Р. Драгићевић (2001: 62) издваја га у придеву добричав. ${ }^{12}$ Дериват добростив могао је настати по аналогији с придевом милостив. ${ }^{13}$

\footnotetext{
${ }^{9}$ Са становишта историјске семантике, садашње примарно значење придева добар више одговара значењу придева благ који се „везивао за сакралну сферу, са додатним семантичким обележјем 'онакав какав треба да буде у духовном погледу', док „придев добар 'онакав какав треба да буде' сужава значење на вредновање физичких карактеристика појма или његове функције” (Грковић-Мејџор 2008: 55).

${ }^{10}$ „Придеви добар и леп - колективно су презасићени, па самим тим и семантички истрошени. У свом значењу задржали су уопштену компоненту позитивног вредновања, која им омогућава да постану синоними и да се употребљавају уз бројне именице различитог значења" (Драгићевић 2007: 139).

${ }^{11}$ Придеви добрахан и добран у РМС означени су као синоними са значењем 'приличан, повелик', и везују се за референте с предметним значењем, те се не могу сматрати фазичним реализацијама придева добар као људске особине.

${ }^{12}$ Иако се у РМС не наводе примери којима се потврђује да се придев добричав односи на човека, ипак ћемо га на основу његове појмовне вредности сматрати припадником ове семантичке класе. У електронским изворима могу се наћи примери с таквом употребом (нпр. Шампион је ... невин, добричав, млад, односно савршен... [http://www.6yka.com/novost/16356/biti-ljubomoranna-novaka-dokovica]).

${ }^{13}$ Са синхронијског становишта могло би се рећи да је придев добростив изведен уланчаним суфиксом -ост-ив, будући да у стандардном језику није потврђен супстантив доброст који
} 
Важна је Скокова напомена у вези с апстрактумом доброст „koje nije ušlo u književnost, ali se čuje i odatle pridjev na -iv: dobrostiv (15. v.)” (1971: 420). У функцији позитивног интензификатора особине садржане у мотивном придеву добар јављају се префикси по- и пре-. На супротној страни фази скале налази се негирани придев недобар са ознаком необ. и у значењу 'зао, рђав'. Дакле, фази скалу са граничним придевом добар чине следећи чланови: недобар - добар - добричав - добростив - подобар - предобар.

Придев добар успоставља антонимску везу с придевима зао и лош која се заснива на супротстављању њихових примарних значења. ${ }^{14}$ Овом антонимском низу може се прикључити и придев рђав у значењу 'који радо наноси другима непријатности и штету, који је лошег карактера, неваљао, покварен, зао’.

Прасловенски придев зао има само психолошко значење (Скок 1973: 642-643) и бројне придевске деривате, од којих су придеви људских особина безазлен 'који је без злобе, пакости, простодушан', злочест 'зао, опак, рђав; несташан, немиран (о деци)', злоћуд и злоћудан 'који је зле ћуди, зле нарави', злопак 'веома зао, опак', злурад' који жели зло другоме, пакостан, злобан'; са истим мотивним придевом је и изведени придев злобан и злобив 'који је пун злобе; који испољава, изражава злобу', у црквеном језику и негирани облик незлобив 'који никоме зла не жели, простодушан'.

Фазични придеви с придевом зао као граничним на фази скали могу имати следећи распоред: безазлен - незлобив - злочест - зао/злоћуд/злоћудан - злобив/злобан - злурад - злопак.

Префиксалима безазлен и незлобив изражава се одсуство особине садржане у мотивној речи. Префикс без- се користи и продуктиван је у семантичком пољу негације и супротности, иако према констатацији Радовић-Тешић (2004: 224), у развојном правцу губи примат у односу на све експанзивније не-, те у оквиру ове лексичко-семантичке скупине испољавају одређене специфичности. Наиме, дериват безазлен истовремено изражава и негацију и супротност значењу које је садржано у творбеној основи (безазлен $\rightarrow$ који није зао и супротно од онога који је зао), али још више носи информацију о одсуству одређене особине (Штасни 2013: 52). У структури придева злочест после мотивисаног дела налази се други део нејасног и немотивисаног значења на синхронијском плану; дијахронијски, према Скоку, долази од зла чест у значењу 'зла судбина' (Клајн 2002: 31). Овај придев сматрамо фазичним с нижим степеном изражености основне особине, будући да поред значења 'зао, опак, рђав' има и значењску компоненту 'несташан, немиран (о деци)'. Сложенице злоћуд и злоћудан својим другим делом конкретизују појам у првом сложеничком делу (зловољан, злонамеран), те се у њима не

би био у функцији творбене основе придева (према лексикализованом милост што је у основи придева милостив).

${ }^{14}$ Основно значење придева зао гласи 'који је склон злу, неваљалству, неваљао, опак, пакостан; који испољава, којим се испољава зло, неваљалство, злурад'; а придева лош 'који је у супротности са уобичајеним мерилима појма доброг, племенитог, човечног и сл., који се својим понашањем, поступцима, односом, карактером и сл. противи уобичајеним, одређеним нормама доброг, позитивног, рђав, неваљао'. 
уочава градабилно својство у односу на придев зао (који је зле ћуди - злоћудан).

Са десне стране фази скале налазе се другостепени придев злобан, у чијој је основи именица злоба 'зао, негативан став према некоме, злурадост, пакост, мржња', мотивисана придевом зао. Истог је деривационог степена и дублетни придев злобив изведен суфиксом -ив. Са појачаним својством је и сраслица злурад са дативним наставком уместо спојног вокала $о$ (Клајн 2002: 93). На крајњој тачки је сложени придев злопак 'веома зао, опак'. ${ }^{15}$

Семантичко-деривациону специфичност испољава придев лош, који има деривиране придева с фазичним појачаним вредностима: олош 'доста лош', прелош 'врло, одвећ лош'. Дакле, изостаје деривација јединица с умањеним или ублаженим степеном особине садржане у мотивном придеву. Распоред на фази скали обухвата следеће јединице: лош - олош - прелош. Фазични придеви су деривирани префиксима $о$ - и пре-. Међутим, придев рђав не мотивише деривацију других фазичних придева.

4.2. У српском језику постоји богат синонимни низ који чине придеви за именовање моралних вредности човека, од којих најближе семантички кореспондирају ваљан - праведан - поштен - частан - добар - крепостан - честит - моралан - карактеран - исправан - правичан - доличан (Ћосић 2008: 81). Међу њима је тешко утврдити прототипичан придев. Ово место би могло припасти придеву поштен с обзиром на то да је његова полисемантична структура у свим својим значењима увек у истом појмовном домену: '1. морално исправан, честит, истинољубив, савестан. 2. који није окаљан ничим недоличним, нечасним, частан. 3. који је онакав какав треба да буде, ваљан'. Придев поштен има у језику реализоване деривате са фазичном вредношћу: непоштен 'који је без осећања поштења и части, који се не држи моралних норми, нечастан, покварен' и препоштен 'сувише, одвећ поштен'. Иако фази скалу чине само три елемента, они обухватају именовани појам у потпуности: непоштен-поштен- препоштен.

Од семантички сродног придева честит 'који није окаљан ничим недоличним, морално исправан, частан, поштен, моралан' деривиран је само префиксал пречестит са значењем 'врло, веома честит'. То, међутим, није случај са придевима који припадају истој семантичкој парадигми. Тако придев частан 'који је у складу са чашћу, морално-етичким нормама, који се држи тих норми, морално исправан, поштен, честит' не индукује деривацију јединица с појачаним основним својством, али мотивише деривацију префиксала у чијој је појмовној вредности у примарној семантичкој реализацији негација бешчастан 'који је без части, нечастан' или одсуство особине исказане мотивним придевом нечастан 'који нема части, бешчастан, непоштен; сраман'.

\footnotetext{
${ }^{15}$ Придев опак има значење 'спреман да учини зло, да напакости, зао, рђав, неваљао; суров, погубан'.
} 


\section{5. Закључак}

Фази лингвистика се заснива на фази логици, која, супротно од аристотеловске логике, посматра одређене феномене у континууму. Фазичне вредности су исказиве како нумеричким тако и језичким средствима. Примена оваквог теоријског приступа посебно је примерена у анализи и тумачењу јединица које у својој концептуалној вредности садрже квалитативне и квантитативне компоненте, што је својствено, у првом реду, придевима.

У раду су анализирани примери који припадају семантичкој групи придева са значењем унутрашње људске особине. Фазична димензија карактеристична је како за концепте који су обухваћени појмом унутрашње особине (интелектуални - емотивни - морални аспект човекове личности међу којима не постоје јасне и оштре границе, већ се међусобно преклапају), тако и за језичке јединице којима се дотичне вредности именују. Тако се, на пример, придевом добар означава карактерна, али и морална, па и интелектуална црта човека (добар човек, добар друг, добар математичар). Зато је у језику тешко идентификовати прототипичне придеве у одређеној поткатегорији (добар / племенит; праведан / частан).

Међутим, како је свака људска особина у својој природи амбивалентна, није довољно утврдити само придев с позитивном концептуалном вредношћу, већ се његова појмовна вредност мора сагледати у тоталитету, укључивањем семантичког опонента и свих фазичних вредности које се реализују од негативних ка граничној вредности, на једној страни, и од граничне вредности ка јединицима које се нижу на позитивном делу скале, с друге стране. Стога је фази скала коју примењујемо у представљању придева са значењем унутрашњих људских особина донекле модификована $(-1-\mathbf{0}-+1)$ у односу на основну (0 и 1), а антонимија је типичан парадигматски однос који се успоставља међу јединицама на негативној и позитивној страни скале.

Придеви с фазичним вредностима у домену менталних својстава човека и његове нарави откривају њихове специфичности на семантичком и деривационом плану. Наиме, пошто основне антонимске парове чине лексеме које се не могу довести у деривацону везу, свака од њих има своје деривате на фазичној скали, а међу појединима се успоставља веза по сличности значења: у групи придева са значењем човекових интелектуалних способности синонимска веза се остварује само међу придевима са значењем одсуства или умањеног својства исказаног прототипичним придевом глуn: беспаметан - непаметан - глупав - глуn; док се међу придевима са значењем карактерног својства човека ова веза остварује међу члановима са обе стране фази скале: добар - безазлен - незлобив и недобар - зао/злоћуд/злоћудан. Иако деривација придева с фазичним вредностима у домену морала није богата, реализовани деривати у потпуности обухватају именовани појам: непоштен - поштен - препоштен.

Као општи закључак наводимо да је фазичност у посматраним семантичким групама придева углавном израженија у негативном делу скале, а када је мотивна реч са значењем непожељне особине, јединице распоређене 
на левој страни скале представљају приближавање неутралном члану, и обрнуто. Са становишта деривације подједнако важну улогу у творби фазичних придева имају одређени суфикси и префикси, док су композите углавном ретке: злоћуд, злоћудан, злурад, злопак.

\begin{tabular}{|l|l|c|c|}
\hline \multicolumn{2}{|c|}{ Префикси } & \multicolumn{2}{c|}{ Суфикси } \\
\hline пре- & $\begin{array}{l}\text { преглуп, препаметан, предобар, прелош, препош- } \\
\text { тен }\end{array}$ & -ав & глупав \\
\hline не- & непаметан, недобар, незлобив, непомтен & -кав & глупкав \\
\hline без- & беспаметан, безазлен & -ичав & добричав \\
\hline по- & подобар & -ан & злобан \\
\hline при- & приглуп & -ив & злобив \\
\hline о- & олош & -остив & добростив \\
\hline
\end{tabular}

Префикси пре-, не-, без- комбинују се са оба члана антонимског пара остварујући своја уобичајена значења, док се при- и $о$ - комбинују са опозитом који садржи негативну страну именоване особине.

Суфикси уносе различите семантичке нијансе у своје деривате, умањујући или ублажавајући својство исказано мотивним придевом (-кав и -ичав), уносећи неко додатно обележје (-aв), стварајући дериват субјективне оцене (-остив), или само као деривационо средство у придевима с основом именице, који су у том случају у конкурентном односу (-ан и -ив).

\section{ЛИТЕРАТУРА}

Гортан-Премк 2004: Д. Гортан-Премк, Полисемија и организација лексичког система у српскоме језику, Београд: Завод за уџбенике.

Грковић-Мејџор 2008: Ј. Грковић-Мејџор, „О семантици старословенских придева добръ и благъ”, Јужнословенски филолог, LXIV, 51-60.

Драгићевић 2001: Р. Драгићевић, Придеви са значењем људских особина у савременом српском језику. Творбена и семантичка анализа, Београд: Институт за српски језик САНУ.

Драгићевић 2007: Р. Драгићевић, Лексикологија српскога језика, Београд: Завод за уџбенике.

Ивић 2005: М. Ивић, „Когнитивни и граматички аспекти евалуације изразом добар (-а, -о)", Јужнословенски филолог, LXI, 1-10.

Клајн 2002: И. Клајн, Творба речи у савременом српском језику. Први део слагање и префиксација, Београд: Завод за уџбенике и наставна средства.

Клајн 2003: И. Клајн, Творба речи у савременом српском језику. Други део суфиксација и конверзија, Београд: Завод за уџбенике и наставна средства, Институт за српски језик САНУ - Нови Сад: Матица српска. 
Костић 2008: Н. Костић, „Антонимија као синтагматска релација: истраживање на корпусу савременог српског језика", Зборник Матище српске за филологију и лингвистику, LI/1-2, 99-117.

Пипер 2002: П. Пипер, „О принципу градуелности у лексикографском опису”, у: Дескриптивна лексикографија стандардног српског језика и њене теоријске основе (Међународни научни скуп о лексикографији и лексикологији), Београд: САНУ, Институт за српски језик САНУ - Нови Сад: Матица српска, 133-139.

Пипер 2008: П. Пипер, „Граматика границе”, Јужнословенски филолог, LXIV, 307-322.

Радовановић 2007: М. Радовановић, „Преглед основних питања везаних за појам градуелности у лингвистици", Зборник Матице српске за филологију и лингвистику, L, 747-757.

Радовановић 2015: М. Радовановић, Фази лингвистика, Сремски Карловци - Нови Сад: Издавачка књижарница Зорана Стојановића.

Радовић-Тешић 2004: М. Радовић-Тешић, „Богаћење лексике префиксацијом", Сриски језик, IX/1-2, 219-226.

РМС 1967-1976: Речник српскохрватскога књижевног језика, Нови Сад: Матица српска.

Скок 1971-1973: P. Skok, Etimologijski rječnik hrvatskoga ili srpskoga jezika, Zagreb: Jugoslavenska akademija znanosti i umjetnosti.

hосић 2008: П. Ћосић и сарадници, Речник синонима, Београд: Kornet.

Шипка 1998: D. Šipka, Osnovi leksikologije $i$ srodnih disciplina, Novi Sad: Matica srpska.

Шипка 2003: D. Šipka, Rečnik tvorbenih formanata, Beograd: Alma.

Штасни 2009: Г. Штасни, „Номинација фази вредности између антонимских полова", Зборник Матице српске за филологију и лингвистику, LII/2, $135-146$.

Штасни 2012: Г. Штасни, Градуелност и антонимија у српском језику, XXXVIII Научна конференција на XLIV меѓународен семинар за македонски јазик, литература и култура, Охрид, 14-15 јули 2011, Скопје, 239-251.

Штасни 2013: Г. Штасни, Речи о човеку (Номинација човека у српском језику), Нови Сад: Филозофски факултет. 
Gordana Štasni

FUZZY ADJECTIVES DENOTING INNER QUALITIES OF A PERSON

\begin{abstract}
Summary
Based on a corpus of selected adjectives which express inner qualities of a person, this paper will examine the possibilities of creating fuzzy values within the semantic subcategory they belong to. Namely, the inner qualities assume personality, intellectual, psychological and emotional qualities of a person, which represent subcategories in the thematic field of "inner qualities". Firstly, the influence of the conceptual value of the motive adjective on the development of gradation is indicated, while the derivational analysis points to the influence of certain suffixes and prefixes on the creation of forms with a fuzzy value.

Key words: adjectives denoting inner qualities of a person, fuzzy values, derivation.
\end{abstract}

